\title{
VH3-21 B Cells Escape from a State of Tolerance in Rheumatoid Arthritis and Secrete Rheumatoid Factor
}

\author{
Xiaowen He, Jörg J. Goronzy, Wanyun Zhong, Congping Xie, \\ and Cornelia $M$. Weyand \\ Department of Medicine, Division of Rheumatology, Mayo Clinic \\ and Foundation, Rochester, Minnesota, U.S.A.
}

\begin{abstract}
Background: Rheumatoid factor (RF) is a characteristic but not pathognomic feature in patients with rheumatoid arthritis (RA). It is unknown whether the repertoire of immunoglobulin genes utilized by $\mathrm{RF}^{+} \mathrm{B}$ cells of RA patients is unique and whether $\mathrm{RF}^{+} \mathrm{B}$ cells in normal individuals are silenced or deleted.

Materials and Methods: Clonal B cell populations were established from the peripheral blood of normal donors (127 B cell clones), RA patients (113 $\mathrm{RF}^{-}$and 60 $\mathrm{RF}^{+} \mathrm{B}$ cell clones) and patients with primary Sjögren's syndrome (82 $\mathrm{RF}^{-}$and $47 \mathrm{RF}^{+} \mathrm{B}$ cell clones) by coculturing with anti-CD3-stimulated $\mathrm{T}$ helper cell clones. The cross-reactivity pattern of antibodies secreted by the $B$ cell clones was determined by ELISA on a panel of antigens. The molecular structure of the IgM heavy chains was characterized by VH family-specific RT-PCR and sequencing. VH elements which correlated with RF specificity were identified. The responsiveness of B cells expressing these $\mathrm{VH}$ elements to $\mathrm{T}$ helper cell signals was compared in normal individuals and RA patients.

Results: The majority of $\mathrm{RF}^{+} \mathrm{B}$ cells were monospecific when specificity was tested on five antigens. $\mathrm{RF}^{+} \mathrm{B}$ cells expressed a significantly different repertoire of $\mathrm{VH}$ gene
\end{abstract}

segments than $\mathrm{RF}^{-} \mathrm{B}$ cells. In particular, the $\mathrm{VH} 3$ gene segment V3-21 was not detected in B cell clones from normals but was the most frequent $\mathrm{VH}$ element in $\mathrm{RF}^{+} \mathrm{B}$ cell clones from RA patients. Most of the V3-2l sequences were in germline configuration. The correlation between RF specificity and V3-21 gene segment usage was maintained in patients with Sjögren's syndrome. V3-2 1 transcripts were present in peripheral blood B cells from normal individuals. $\mathrm{VH} 3-2 \mathrm{l}^{+} \mathrm{B}$ cells from RA patients but not from normal donors were responsive to preactivated $\mathrm{T}$ helper cells. Stimulation with a bacterial superantigen could overcome the nonresponsiveness of V3-2 $1^{+} \mathrm{B}$ cells in normal donors and induce the secretion of RF.

Conclusions: RF production is correlated with the usage of the V3-21 gene segment in two distinct $\mathrm{RF}^{+}$diseases. In patients with these diseases, $\mathrm{V} 3-21^{+} \mathrm{B}$ cells secrete antibodies with RF activity in response to activated $\mathrm{T}$ helper cells. $\mathrm{V} 3-2 \mathrm{I}^{+} \mathrm{B}$ cells remain in a state of nonresponsiveness in normal individuals that can be broken by superantigen stimulation. The germline configuration of $\mathrm{VH} 3-2 \mathrm{I}^{+} \mathrm{RF}^{+}$immunoglobulins in RA patients suggests that the loss of tolerance is not an antigen-driven process.

\section{INTRODUCTION}

Rheumatoid factor $(\mathrm{RF})$ recognizing the $\mathrm{FC}$ portion of IgG molecules makes up the majority of the autoantibodies produced by patients with rheumatoid arthritis (RA) (1-3). Although most frequently found in RA, production of RF is neither consistently associated with RA nor is it specific for RA. In particular, patients with primary Sjögren's syndrome (pSS), scleroderma, and mixed connective

Address correspondence and reprint requests to: C. M. Weyand, Mayo Clinic, 401 Gugg., 200 First Street, SW, Rochester, MN 55905, U.S.A. tissue disease can have circulating antibodies that react with IgG Fc epitopes (1). RF can also be produced by normal individuals, and an increase in titers of IgM RF is a phenomenon frequently encountered in patients with ongoing chronic immune responses such as bacterial endocarditis or transplantation $(4,5)$. For several decades, RF has been considered to be involved in the pathogenetic events and the inflammatory response of RA. The observation that RF undergoes affinity maturation in RA has supported the model that it is the products of an antigen-driven response, possibly initiated or maintained by a disease causative antigen. 
More recently, a different view of RF and $\mathrm{RF}^{+} \mathrm{B}$ cells has emerged (6). Evidence has been presented that $\mathrm{RF}^{+} \mathrm{B}$ cells serve important physiological functions. Their ability to bind IgG-containing immunocomplexes may give them a clearing function and enable them to bind and present antigenic peptides from antigens bound in immune complexes (7). Generally, B cells are able to take up their specific antigen at much lower antigen concentrations than other professional APC $(8,9)$. Thus, $\mathrm{RF}^{+} \mathrm{B}$ cells could represent a population of APC that express a wide variety of antigenic peptides in their HLA molecules reflecting upon the antigens trapped in IgG complexes.

Provided that $\mathrm{RF}^{+} \mathrm{B}$ cells are present in the normal immune repertoire and serve an important physiological function as APC for antigens present in the form of immune complexes with IgG, these cells are obviously not clonally deleted (10). It is unclear how $\mathrm{RF}^{+} \mathrm{B}$ cells in normal individuals are maintained in a functional state which allows them to bind IgG antigen complexes through their membrane-anchored immunoglobulin but prevents secretion of this immunoglobulin. By using a transgenic mouse model for human IgM RF, Tighe et al. have provided in vivo evidence for the model that $\mathrm{RF}^{+} \mathrm{B}$ cells are important in antigen presentation (11). Interestingly, despite functional competence of $\mathrm{RF}^{+} \mathrm{B}$ cells in these mice, antibodies with anti-Fc reactivity were not secreted. Secretion of $\mathrm{RF}$ could be induced by introducing a gene of the MRL/lpr background, and the authors have hypothesized that similar mechanisms may underlie the secretion of RF in the absence of a known antigenic stimulus in diseases such as RA and pSS. As an alternative model, it has been suggested that the production of an RF autoantibody is closely linked to affinity maturation. Somatic mutation and class switching are infrequent events in RF produced by normal individuals (12). In contrast, RA patients may lack the ability to control affinity maturation of RF-producing B cells resulting in the selection of somatically mutated, high affinity RF.

The analysis of the regulation of RF-producing $B$ cells in patients with RA has been hampered due to the fact that $\mathrm{RF}^{+} \mathrm{B}$ cells in RA patients cannot be easily identified. Here, we report that IgM $\mathrm{RF}^{+} \mathrm{B}$ cells in patients are characterized by a unique immunoglobulin gene segment usage providing a molecular marker for this B cell subset. By studying the IgM heavy chain of B cell clones established from peripheral blood of RA patients and normal individuals, we have found a correlation between the expression of the VH gene segment V3-2l and RF specificity. $\mathrm{V} 3-2 \mathrm{I}^{+} \mathrm{B}$ cells were present in the repertoire of normal individuals, but they did not proliferate to signals provided by anti-CD3 activated $\mathrm{T}$ helper cells. In contrast, $\mathrm{V} 3-2 \mathrm{l}^{+} \mathrm{B}$ cell clones could be established from the peripheral blood of patients with RA. These B cells preferentially secreted monospecific RF, however, the IgM heavy chain did not show any evidence for somatic mutation. Similar results were obtained from patients with pSS, another disease which is characterized by the production of RF. Our data suggest that patients with RA and pSS share a regulatory defect in controlling the activation of these RF-producing B cells, which remain nonsecreting $B$ cells in normal individuals.

\section{MATERIALS AND METHODS}

\section{Study Population}

Thirteen patients with seropositive RA, 13 normal individuals, and two patients with pSS were studied. All patients with RA fulfilled the American College of Rheumatology diagnostic criteria (13). The normal donors did not have a personal or family history of an inflammatory rheumatic disease, and all of them tested negative for RF. The two patients with pSS fulfilled five classification criteria proposed for the diagnosis of pSS (14). They were positive for RF, anti-SS-A, and anti-SS-B antibodies but lacked clinical features suggestive of RA, SLE, polymyositis, or scleroderma. In particular, they did not have erosive joint disease.

\section{Generation of B Cell Clones}

B cell clones were established by coculturing a limited number of B cells (3-5 cells/well) with anti-CD3 activated clonal $T$ cells as recently described (15). In brief, B cells were purified from PBMC by treatment with $50 \mathrm{mM}$ L-leucine methyl ester $\mathrm{HCl}$ (Sigma Chemical Co., St. Louis, MO, U.S.A.) for $45 \mathrm{~min}$ at room temperature and subsequent rosetting of the surviving cell population with AET-treated sheep red blood cells (16). Nonrosetting cells were highly enriched in B cells and contained between 75 and $90 \%$ of CD $19^{+}$lymphocytes as demonstrated by FACS analysis. The T cell clone LAB1-10, used in this study, is alloreactive and recognizes HLA- 
$\mathrm{DRB} 1^{*} 0404^{+}$stimulator cells, as previously described. None of the $B$ cell donors expressed an allogeneic specificity recognized by LAB1-10 (data not shown). B cell clones were established by coculturing $1 \times 10^{5}$ cloned $\mathrm{T}$ cells (LAB $1-10$ ) with three to five $B$ cells per well in 96-well flat-bottom tissue culture plates coated with antiCD3 mAb. After 11 days, microcultures were fed with $20 \mathrm{U} / \mathrm{ml} \mathrm{rIL-2}$ (Cetus). In selected experiments, $\mathrm{B}$ cell lines were established by coculturing $5 \times 10^{3} \mathrm{~B}$ cells with $1 \times 10^{5} \mathrm{LAB} 1-10$ in the presence of immobilized anti-CD3 and $1 \mu \mathrm{g} / \mathrm{ml}$ staphylococcal enterotoxin D (SE D) (Toxin Technology, Sarasota, FL, U.S.A.), respectively.

\section{Antibody Specificity Testing}

Culture supernatants were collected after 18-21 days of culture and total IgM and antibody specificity were determined in an ELISA assay. To determine IgM, a sheep anti-human immunoglobulin (Sigma) was coated to maxisorb plates (Nunc Inc., Naperville, IL, U.S.A.). After blocking, plates were incubated with undiluted supernatants and then incubated with alkaline phosphatase coupled goat anti-human IgM (Boehringer-Mannheim, Indianapolis, IN, U.S.A.). To identify RF-producing cultures and to determine cross-reactivity patterns, plates were coated with human Ig-Fc fragments (Calbiochem-Behring Corp., San Diego, CA, U.S.A.), actin, keratin, single stranded DNA, thyroglobulin (Sigma), and tetanus toxoid (Behring Werke, Marburg, Germany), respectively. Subsequently, the plates were incubated with the supernatants. Alkaline phosphatase coupled goat anti-human $\kappa$ - and $\lambda$-chain-specific anti-sera were used as developing antibodies. Serial dilutions of purified antibodies or sera with known antibody titers were included as positive controls. All assays were developed using p-nitrophenol phosphate in $10 \mathrm{mM}$ diethanolamine buffer. Supernatants from cultures without any B cells were used as negative controls. Microcultures with signal intensities of at least three standard deviations larger than the signals from the control cultures were identified as positive.

\section{Molecular Characterization of IgM Heavy Chains}

Microcultures positive for IgM were identified and the cloning efficiency was determined. Cells from microcultures which were likely to be clonal were harvested, washed with phosphatebuffered saline (PBS), and lysed with $4 \mu \mathrm{l}$ of NP40 lysis buffer ( $1 \% \mathrm{NP} 40,10 \mathrm{mM}$ Tris $\mathrm{HCl}$, $10 \mathrm{mM} \mathrm{NaCl}, 3 \mathrm{mM} \mathrm{MgCl}_{2}, \mathrm{pH} 8.0$, and $0.5 \mathrm{U}$ RNAse inhibitor). cDNA was synthesized in a total volume of $20 \mu \mathrm{l}$ by incubation with $0.5 \mathrm{U}$ AMV reverse transcriptase for $2 \mathrm{hr}$ at $37^{\circ} \mathrm{C}$. cDNA was amplified by polymerase chain reaction (PCR) using two mixtures of two $\mathrm{VH}$-specific primers (GGTGCAGCTGGTGCAGTCTGG and GGTCAA CTTAAGGGAGTCTGG, GGACTGGTGAAGCCT TCGG and GGTACAGCTGCAGCAGTCAGG) and a $\mathrm{C} \mu$ primer (GGAATTCTCACAGGAGACGAG). These primer combinations amplified all VH gene families as previously shown (17). The amplified products were reamplified using internal VH family-specific primers (VHl, GTGAAGGTTTCCTG CAAGGCT; VH2, CTGACACTGAACTGCACCTTC; VH3, CTGAGACTCTCCTGTGCAGCC; VH4, CTG TCCCTCACCTGCGCTGTC; VH5, GGGGAGTCTCT GAGGATCTCC; VH6, CTCTCACTCACCTGTGCCA TC) and an internal $\mathrm{C} \mu$ primer (TGGGGCGGATG CACTCCC). Amplified products were separated on agarose gels and identified by ethidium bromide staining.

$\mathrm{VH}^{+}$sequences were amplified using the $\mathrm{C} \mu$ primer and a VH3 family-specific primer, either one of which was attached to a T7 promoter. The amplified products were transcribed using a T7 RNA polymerase, and the transcripts were sequenced by transcriptase-mediated dideoxysequencing using a ${ }^{32} \mathrm{P}$-endlabeled internal $\mathrm{C} \mu$ and a VH3 primer, respectively, as a reverse transcriptase primer as recently described $(17,18)$. Sequences were read in both directions. All sequence reactions yielded unequivocal sequences, again supporting the concept that the microcultures were truly clonal. B cell clones were assigned to published sequences of the $\mathrm{VH} 3, \mathrm{DH}$, and $\mathrm{JH}$ germline genes (19-27). DH segments were assigned using the criteria recently described (28).

\section{Oligonucleotide Hybridization Assays with V3-21- and V3-23-Specific Primers}

The frequency of V3-21 and V3-23 transcripts was semiquantified in freshly separated PBMC from 10 patients with RA and 10 normal controls and in $\mathrm{B}$ cell lines cocultured with $\mathrm{T}$ cell clones stimulated with either immobilized anti-CD3 or the SE D by using an oligonucleotide hybridization assay as recently described (29). cDNA was amplified with VH3- and IgM-specific primers. 
TABLE 1. Frequencies of RF-secreting B cells in peripheral blood B cells from normal controls and patients with rheumatoid arthritis (RA) and primary Sjögren's syndrome (pSS)

\begin{tabular}{lccc}
\hline B Cell Donors & $\begin{array}{c}\text { Number of } \\
\text { Microcultures }\end{array}$ & $\begin{array}{c}\text { IgM }^{+} \\
\text {Cultures }\end{array}$ & $\begin{array}{c}\mathbf{R F}^{+} / \mathbf{I g M}^{+} \\
\text {Cultures }\end{array}$ \\
\hline Normal controls $(n=4)$ & 544 & 149 & $0.7 \%$ \\
RA patients $(n=5)$ & 2128 & 439 & $14.9 \%$ \\
pSS patients $(n=2)$ & 1536 & 386 & $12.7 \%$ \\
\hline
\end{tabular}

Serial dilutions of the amplified product were dot blotted onto supported nitrocellulose membranes (BioRad, Hercules, CA, U.S.A.). Membranes were prehybridized in $55^{\circ} \mathrm{C}$ in $2 \times$ SSPE, $5 \times$ Denhardt's, $0.1 \%$ SDS, and denatured salmon DNA and hybridized with a biotinylated IgM-specific probe (AGGGTTGGGGCGGATG CACTC; Biotin-On, Phosphoramidite, Clonotech, Palo Alto, CA, U.S.A.) overnight. The membranes were then washed in $2 \times$ SSC $+1 \%$ SDS at $45^{\circ} \mathrm{C}$ for $10 \mathrm{~min}, 55^{\circ} \mathrm{C}$ for $5 \mathrm{~min}$, and $0.2 \times$ $\mathrm{SSC}+0.1 \%$ SDS at $65^{\circ} \mathrm{C}$ for $5 \mathrm{~min}$. Membranes were blocked, incubated with streptavidin-alkaline phosphatase (DAKO, Carpenteria, CA, U.S.A.) and then developed using 5-bromo-4-chloro-3 indolyl phosphate and 4 nitro-blue tetrazolium chloride in a buffer containing $100 \mathrm{mM}$ Tris $\mathrm{HCl}$, $100 \mathrm{mM} \mathrm{NaCl}, 50 \mathrm{mM} \mathrm{MgCl}_{2}$, and $\mathrm{pH}$ 9.5. The blots were scanned using an AMBIS optical imaging system (San Diego, CA, U.S.A.). Amplified products were adjusted to contain equal amounts of IgM sequences, dot blotted, and hybridized with V3-21 (CCATTAGTAGTAGTAGTAGTTA) and V3-23-specific (CTATTAGTGGTAGTGGTGG TAG) biotinylated probes. The blots were hybridized, washed at 45 and $55^{\circ} \mathrm{C}$, and developed as described above. The probes were specific for the appropriate $\mathrm{VH}$ sequences as determined on $\mathrm{VH} 3$ gene sequences derived from clonal B cell populations (data not shown).

\section{Statistical Analysis}

The distribution of $\mathrm{VH}, \mathrm{JH}$, and $\mathrm{DH}$ gene segment usage in the different $\mathrm{B}$ cell population was compared using a Pearson chi-square test. The frequencies of individual germline gene segment usage were compared by chi-square test or Fisher's exact test if appropriate.

\section{RESULTS}

Generation of RF-Producing B Cell Clones

To correlate antibody specificity, molecular characteristics of the IgM heavy chain and functional response to $\mathrm{T}$ cell signals, we have used a culture system in which clonal B cell populations were expanded in the presence of anti-CD3-activated $\mathrm{T}$ helper cells. To control for diversity of $\mathrm{T}$ helper cells, all experiments were done with a single $\mathrm{T}$ helper cell clone. B cells derived from patients and normal donors were examined in parallel cultures. Supernatants of established cultures were tested for antigen reactivity. As given in Table 1, secretion of IgM was detected in about $25 \%$ of the microcultures, which corresponded to a B cell cloning efficiency of $1: 4$ to $1: 5$. In healthy individuals, $0.7 \%$ of these IgM antibodies had Fc-binding specificity characterizing them as RF. The frequency of $\mathrm{RF}^{+}$secreting $\mathrm{B}$ cells was 20 -fold increased in rheumatoid patients. Patients with pSS shared with RA patients the increased frequencies in $\mathrm{RF}^{+} \mathrm{B}$ cells.

\section{Specificity of $\mathbf{R F}^{+}$B Cells Isolated from the Peripheral Blood of $\mathrm{RF}^{+}$Patients}

To address the issue whether the RF produced by $B$ cell clones from patients with pSS and RA represented monoreactive anti-Fc antibodies or polyreactive natural autoantibodies, supernatants from $42 \mathrm{~B}$ cell clones with RF activities from RA patients and 26 clones from patients with pSS were tested on a panel of soluble antigens. Only 8 of the 68 antibodies were truly polyreactive and had a broad cross-reactivity pattern (Table 2). Forty-five antibodies were monospecific for Fc fragments, and, within the panel of antigens tested, no cross-reactivity was observed. These data suggest that the majority of RF produced under these culture conditions did not 
TABLE 2. Cross-reactivity pattern of rheumatoid factors

\begin{tabular}{ccccccc}
\hline \multirow{2}{*}{$\begin{array}{l}\text { No. of } \\
\text { Clones }\end{array}$} & \multicolumn{7}{c}{ Antibody Reactivity } \\
\cline { 2 - 7 } & IgG Fc & Actin & Keratin & ssDNA & Thyroglobulin & Tetanus Toxoid \\
\hline 2 & + & + & + & + & + & + \\
1 & + & + & + & + & + & - \\
1 & + & + & + & - & - & + \\
1 & + & + & - & - & + & + \\
1 & + & - & + & + & + & + \\
1 & + & - & + & + & - & - \\
1 & + & - & + & + & - & - \\
1 & + & + & - & - & - & - \\
4 & + & - & + & - & - & + \\
3 & + & - & - & + & - & - \\
3 & + & - & - & - & - & + \\
4 & + & - & - & - & - & - \\
45 & + & - & - & - & & - \\
\end{tabular}

represent natural autoantibodies. Patients with RA and pSS exhibited the same pattern of specificities. Twenty-four of the monospecific RF were derived from RA patients and 21 from patients with pSS.

\section{Molecular Characteristics of Immunoglobulins with RF Reactivity}

To identify the molecular characteristics of immunoglobulins with RF reactivity, VH gene family usage was analyzed in $\mathrm{RF}^{+}$and $\mathrm{RF}^{-} \mathrm{B}$ cell clones derived from normal donors, RA patients, and pSS patients. The results are shown in Table 3. One hundred twenty-seven $\mathrm{B}$ cell clones from normal individuals were studied, all of them were negative for RF reactivity. Among these $127 \mathrm{~B}$ cell clones, the VH3 gene family was predominantly used. The distribution of $\mathrm{VH}$ gene families was not different from that in $113 \mathrm{RF}^{-} \mathrm{B}$ cell clones from RA patients, while it significantly differed from the $\mathrm{VH}$ distribution in $\mathrm{RF}^{+} \mathrm{B}$ cells $(p=0.001)$. Of the RF secreting B cells derived from RA patients, $77 \%$ belonged to the $\mathrm{VH} 3$ family, compared with $50 \%$ in the $\mathrm{RF}^{-} \mathrm{B}$ cells from RA patients and $42 \%$ in healthy individuals. Similarly, VH3 elements were overrepresented in $\mathrm{RF}^{+} \mathrm{B}$ cells from pSS patients.

VH3 is the most complex family of gene segments with 37 different variants mapped so far. To address the question whether a correlation exists between germline diversity and RF speci-

TABLE 3. VH gene segment usage in IgM heavy chains from $\mathbf{R F}^{+}$and $\mathrm{RF}^{-} \mathrm{B}$ cells

\begin{tabular}{|c|c|c|c|c|c|c|c|c|c|}
\hline \multirow[b]{2}{*}{ Donors } & \multirow[b]{2}{*}{ Specificity } & \multirow{2}{*}{$\begin{array}{l}\text { No. of } \\
\text { Clones }\end{array}$} & \multicolumn{6}{|c|}{ Frequency (\%) } & \multirow{2}{*}{$\begin{array}{c}p \\
\text { Patients Versus } \\
\text { Normal Controls }\end{array}$} \\
\hline & & & VHI & VH2 & VH3 & VH4 & VH5 & VH6 & \\
\hline Normal controls & $\mathrm{RF}^{-}$ & 127 & 30.7 & 3.9 & 42.5 & 8.7 & 12.6 & 1.6 & N/A \\
\hline \multirow[t]{2}{*}{ RA patients } & $\mathrm{RF}^{-}$ & 113 & 23.0 & 3.5 & 50.4 & 16.8 & 4.4 & 1.8 & NS \\
\hline & $\mathrm{RF}^{+}$ & 60 & 13.3 & 1.7 & 76.7 & 3.3 & 3.3 & 1.7 & 0.001 \\
\hline \multirow[t]{2}{*}{ pSS patients } & $\mathrm{RF}^{-}$ & 82 & 24.4 & 2.4 & 43.9 & 12.2 & 11.0 & 6.1 & NS \\
\hline & $\mathrm{RF}^{+}$ & 47 & 21.3 & 2.1 & 61.7 & 6.4 & 4.3 & 4.3 & NS \\
\hline
\end{tabular}


TABLE 4. Usage of VH3 gene segment subtypes in IgM heavy chains from $\mathrm{RF}^{+}$and $\mathrm{RF}^{-} \mathrm{B}_{\text {cells }}$

\begin{tabular}{|c|c|c|c|c|c|c|c|c|}
\hline \multirow[b]{2}{*}{ Donors } & \multirow[b]{2}{*}{ Specificity } & \multirow{2}{*}{$\begin{array}{l}\text { No. of } \\
\text { Clones }\end{array}$} & \multicolumn{5}{|c|}{ Frequency (\%) } & \multirow{2}{*}{$\begin{array}{c}p \\
\text { Patients Versus } \\
\text { Normal Controls }\end{array}$} \\
\hline & & & V3-23 & V3-30 & V3-21 & V3-15 & Others & \\
\hline Normal controls & $\mathrm{RF}^{-}$ & 33 & 39.4 & 27.3 & 0.0 & 3.0 & 30.3 & N/A \\
\hline \multirow[t]{2}{*}{ RA patients } & $\mathrm{RF}^{-}$ & 34 & 17.6 & 20.6 & 5.9 & 8.8 & 47.1 & NS \\
\hline & $\mathrm{RF}^{+}$ & 31 & 16.1 & 13.0 & 19.4 & 16.1 & 35.5 & 0.007 \\
\hline \multirow[t]{2}{*}{ pSS patients } & $\mathrm{RF}^{-}$ & 27 & 18.5 & 25.9 & 7.7 & 3.7 & 44.4 & NS \\
\hline & $\mathrm{RF}^{+}$ & 27 & 11.1 & 37.0 & 14.8 & 0.0 & 37.0 & 0.03 \\
\hline
\end{tabular}

ficity, we determined $\mathrm{VH} 3$ subtypes in $\mathrm{VH}^{+}{ }^{+} \mathrm{B}$ cell clones in the $\mathrm{RF}^{-} \mathrm{B}$ cells from normal individuals, the $\mathrm{RF}^{-}$and $\mathrm{RF}^{+} \mathrm{B}$ cells from RA patients, and in the $\mathrm{RF}^{-}$and $\mathrm{RF}^{+} \mathrm{B}$ cells in pSS patients. The results are summarized in Table 4 . Two germline gene segments, V3-23 and V3-30, were dominant in B cell clones established from normal individuals. These two germline segments accounted for $67 \%$ of the $\mathrm{VH}^{+}$B cell clones analyzed. V3-23 and V3-30 were less prominent in the population of RF producing $B$ cells from RA patients. Only $29 \%$ expressed a V3-23 or V3-30 gene segment. Two VH3 segments, V3-21 and V3-15, were more frequent in the repertoire of $\mathrm{RF}^{+} \mathrm{B}$ cells. In particular, V3-21, which was the most frequent VH3 element in $\mathrm{RF}^{+} \mathrm{B}$ cells from $\mathrm{RA}$ patients, was not detected in $B$ cell clones from normal individuals. The distributions of VH3 gene segment usage in normal individuals and $\mathrm{RF}^{+} \mathrm{B}$ cells of RA patients were significantly different at the $p=0.007$ level. The biased usage of VH3 subtypes correlated with the RF specificity of the antibodies, however, a similar but less pronounced trend was also evident for the $\mathrm{RF}^{-} \mathrm{B}$ cells from RA patients. The V3-23 segment was generally underrepresented in RA $B$ cell clones irrespective of their RF reactivity. In contrast to normal individuals, $\mathrm{V} 3-21^{+} \mathrm{B}$ cell clones were found in the population of $\mathrm{RF}^{-} \mathrm{B}$ cells from RA patients, albeit at a more less frequency than in $\mathrm{RF}^{+} \mathrm{B}$ cells.

In summary, B cells from RA patients express a unique repertoire of $\mathrm{VH} 3$ gene segments characterized by a reduction in V3-23 usage and the presence of V3-21. This fingerprint is present in $\mathrm{RF}^{+}$and in $\mathrm{RF}^{-} \mathrm{B}$ cells of RA patients. However, there is a marked increase of V3-21 expression in $\mathrm{RF}^{+} \mathrm{B}$ cells, suggesting that an association exists between V3-21 and RF specificity.

This interpretation is further supported by the finding that $\mathrm{RF}^{+} \mathrm{B}$ cell clones derived from patients with pSS also used the V3-2l gene segment more frequently. The $\mathrm{VH} 3$ repertoire of $\mathrm{RF}^{+} \mathrm{B}$ cell clones from pSS patients differed significantly from the distribution in the $\mathrm{RF}^{-}$population of normal controls $(p=0.03)$. Again, a similar trend was seen for the $\mathrm{RF}^{-} \mathrm{B}$ cell clones derived from pSS patients, however, the shifts were much less pronounced (Table 4). Compared to $\mathrm{RF}^{+} \mathrm{B}$ cell clones from RA patients, pSS patients used the V3-30 gene element more frequently. Our data suggest that the $\mathrm{VH}$ repertoire of B cells from patients with RA and pSS which are responsive to the $\mathrm{T}$ cell derived stimuli are different compared with normal controls. These differences are shared between the two diseases and closely relate to the high number of RF secreting cells.

The five B cell populations $\left(\mathrm{RF}^{-} \mathrm{B}\right.$ cell clones of normal individuals, and $\mathrm{RF}^{-}$and $\mathrm{RF}^{+} \mathrm{B}$ cell clones from patients with RA and pSS) were also compared for $D$ and $J$ gene segment usage (Tables 5 and 6). All sets of B cells preferentially utilized the $\mathrm{JH} 4$ gene segment for assembly of the Ig molecule. Between 50 and $70 \%$ of all B cell clones transcribed the JH4 gene segment. There was no significant differences in the distribution of JH gene segment usage.

D elements could be assigned to approximately $90 \%$ of the sequences. The D gene segment usage was heterogeneous and involved all different families with the exception of DHQ52. Again, there was no obvious difference in the distribution of $D$ gene segment usage when the $B$ cells from normal individuals and patients with and without RF specificity were compared.

Comparison of the amino acid sequences of the third complementarity determining region (CDR3) did not reveal any sequence homology in the $\mathrm{B}$ cell clones with RF activity (data not 
TABLE 5. JH gene segment usage in $\mathrm{VH}^{+}{ }^{+} \mathrm{IgM}$ antibodies

\begin{tabular}{|c|c|c|c|c|c|c|c|c|}
\hline \multirow[b]{2}{*}{ Donors } & \multirow[b]{2}{*}{ Specificity } & \multirow{2}{*}{$\begin{array}{l}\text { No. of } \\
\text { Clones }\end{array}$} & \multicolumn{6}{|c|}{ Frequency $(\%)$} \\
\hline & & & JHI & JH2 & JH3 & JH4 & JH5 & JH6 \\
\hline Normal controls & $\mathrm{RF}^{-}$ & 33 & 3.0 & 6.1 & 6.1 & 54.5 & 15.2 & 15.2 \\
\hline \multirow[t]{2}{*}{ RA patients } & $\mathrm{RF}^{-}$ & 34 & 0.0 & 2.9 & 5.9 & 55.9 & 8.8 & 26.5 \\
\hline & $\mathrm{RF}^{+}$ & 31 & 0.0 & 3.2 & 3.2 & 71.0 & 3.2 & 19.4 \\
\hline \multirow[t]{2}{*}{ pSS patients } & $\mathrm{RF}^{-}$ & 24 & 4.2 & 0.0 & 16.7 & 50.0 & 12.5 & 16.7 \\
\hline & $\mathrm{RF}^{+}$ & 23 & 0.0 & 13.0 & 17.4 & 52.2 & 4.3 & 13.0 \\
\hline
\end{tabular}

shown). VH gene segment sequences were compared with the assigned germline gene segment sequences, and the mutations were analyzed to address the question of whether RF from either patients with RA or with pSS displayed evidence for somatic mutation. In all populations studied, the number of mutations were small. In about $90 \%$ of all sequences, either none or only one mutation was identified. The mutations found were randomly distributed, were not clustered in the CDR regions, and were not enriched for replacement mutations. No differences were seen between $\mathrm{RF}^{-}$and $\mathrm{RF}^{+} \mathrm{B}$ cell clones. Seventy-two percent of all $\mathrm{RF}^{+} \mathrm{B}$ cell clones from RA patients did not have any mutation in the $\mathrm{V}$ region and $14 \%$ had only a single mutation. These results were not different from the B cell clones without RF activity (60 and $27 \%$, respectively). Results in the pSS cohort were very similar with no mutation in $59 \%$ of the $\mathrm{RF}^{+}$and $60 \%$ of the $\mathrm{RF}^{-}$ clones and one mutation in $27 \%$ of the $\mathrm{RF}^{+}$and $25 \%$ of the $\mathrm{RF}^{-} \mathrm{B}$ cells.

\section{V3-21 B Cells Are Not Deleted from the Repertoire of Normal Donors}

The presence of $\mathrm{V} 3-21^{+}$-expressing $\mathrm{B}$ cells distinguished normal individuals from patients with RA and pSS. It is possible that patients and normal individuals differ in the germline repertoire. A second possibility is that $\mathrm{V} 3-21^{+}$B cells are preferentially deleted because they correlate with RF specificity and therefore have a higher potential to be autoreactive. To address these possibilities, B cells were purified from PBMC of 10 normal individuals and 10 RA patients and were semiquantified for the expression of V3-23 and V3-21 sequences. RNA was amplified by RTPCR with a VH3-IgM-specific primer set. The amplification product was adjusted for equal amounts of immunoglobulin sequences by hybridization with an IgM-specific probe. The adjusted material was then hybridized with oligonucleotides specific for V3-21 and V3-23. Specificity of both oligonucleotides was established in hybridization assays with $\mathrm{VH} 3$ sequences derived from

TABLE 6. DH gene segment usage in $\mathrm{VH}^{+}{ }^{+}$IgM antibodies

Frequency (\%)

\begin{tabular}{|c|c|c|c|c|c|c|c|c|c|c|c|c|}
\hline \multirow[b]{2}{*}{ Donors } & \multirow[b]{2}{*}{ Specificity } & \multirow{2}{*}{$\begin{array}{l}\text { No. of } \\
\text { Clones }\end{array}$} & \\
\hline & & & DXP & DA & DLR & DK & DN & DM & DHF16 & DIR & DHQ52 & Unknown \\
\hline Normal controls & $\mathrm{RF}^{-}$ & 33 & 39.4 & 0.0 & 21.2 & 6.1 & 18.2 & 12.1 & 0.0 & 9.1 & 0.0 & 6.1 \\
\hline \multirow[t]{2}{*}{ RA patients } & $\mathrm{RF}^{-}$ & 34 & 38.2 & 2.9 & 11.8 & 17.6 & 20.6 & 0.0 & 5.9 & 2.9 & 0.0 & 8.8 \\
\hline & $\mathrm{RF}^{+}$ & 31 & 35.5 & 6.5 & 6.5 & 22.6 & 16.1 & 3.2 & 9.7 & 0.0 & 0.0 & 6.5 \\
\hline \multirow[t]{2}{*}{ pSS patients } & $\mathrm{RF}^{-}$ & 24 & 54.2 & 0.0 & 8.3 & 8.3 & 4.2 & 4.2 & 4.2 & 4.2 & 0.0 & 20.8 \\
\hline & $\mathrm{RF}^{+}$ & 23 & 30.4 & 4.3 & 34.8 & 13.0 & 8.7 & 0.0 & 8.7 & 0.0 & 0.0 & 4.3 \\
\hline
\end{tabular}




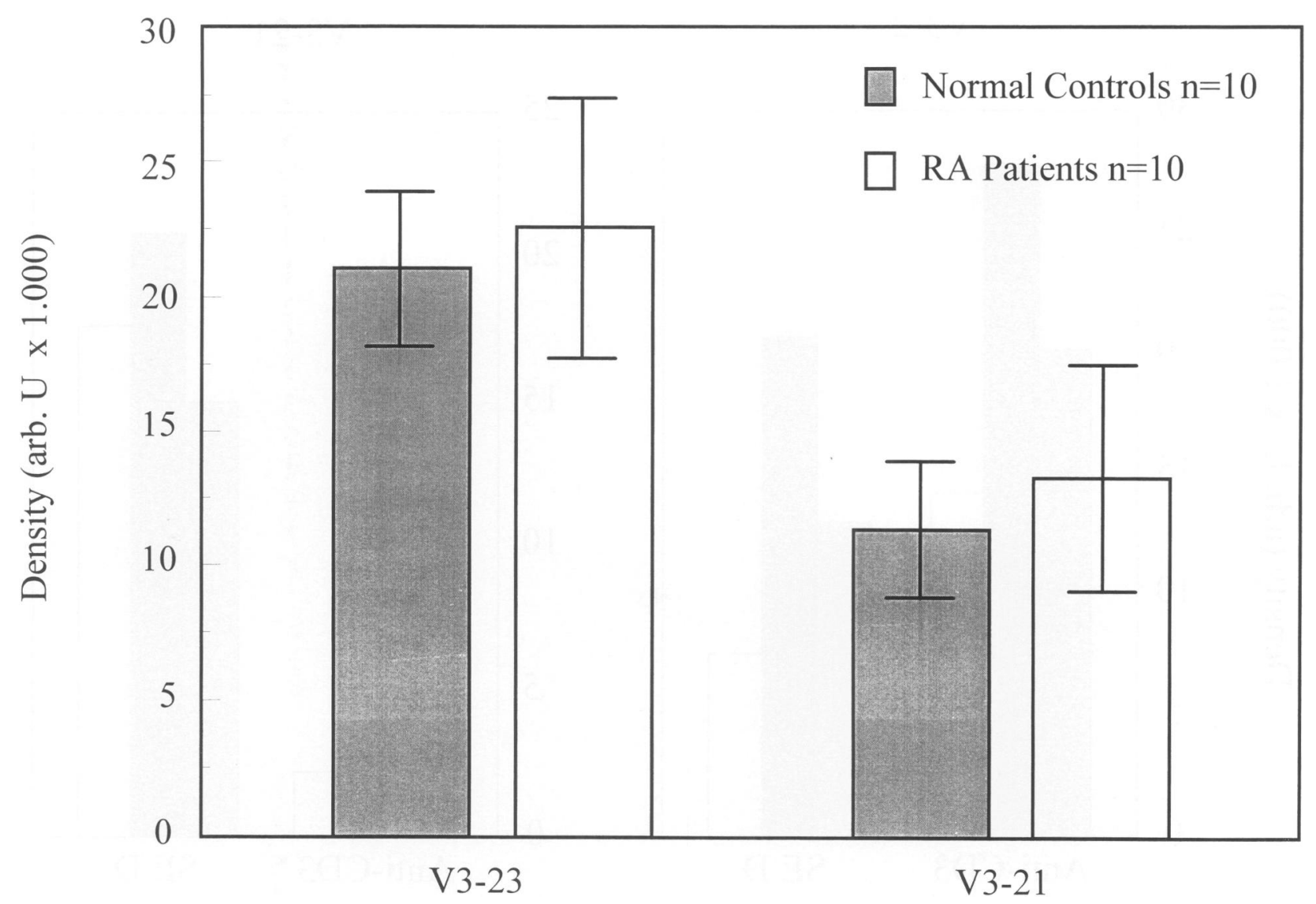

FIG. 1. Expression of V3-23 and V3-21 transcripts in unstimulated peripheral B cells of normals and RA patients

Peripheral blood lymphocytes were isolated from 10 normal donors and 10 RA patients. cDNA was amplified with VH3 and IgM specific primers. Amplified products were adjusted for equal amounts of IgM transcripts, dot blotted onto nitrocellulose membranes, and hybridized with biotinylated oligonucleotide probes specific for V3-21 or V323. The binding of the oligonucleotides was semiquantified using an Ambis system. Average densities of the V3-23 and V3-21 probes bound to VH3-specific transcripts from normal donors and RA patients are given.

sequenced B cell clones. The oligonucleotide hybridization assays were scanned using an AMBIS imaging system. Results are summarized in Fig. 1. All 20 donors (10 normal individuals and 10 RA patients) expressed the V3-21 as well as the V3-23 transcripts. While variations in the level of expression of V3-21 and V3-23 were detected in different individuals, there was no correlation with the presence of RA. The mean density for both VH3 elements was not different when normal donors and RA patients were compared (Fig. 1). These results demonstrate that $\mathrm{V} 3-21^{+} \mathrm{B}$ cells exist in the repertoire of normal individuals but apparently are not activated when cocultured with anti-CD3-stimulated helper T cells.

\section{Nonresponsiveness of V3-21 B Cells Derived from Normal Donors Can Be Overcome}

Our data indicated that $\mathrm{V} 3-2 \mathrm{1}^{+} \mathrm{B}$ cells are present in the repertoire of normal individuals but they remained nonresponsive to anti-CD3stimulated $\mathrm{T}$ cell clones. To further address this hypothesis, we explored different stimulation conditions with the goal to identify stimuli that could activate V3-21 B cells from normal individuals. We have recently described that the bacterial superantigen SE D can induce the preferential production of antibodies with RF specificity. Molecular analysis has indicated that the $\mathrm{B}$ cell population responsive to SE D includes $\mathrm{V} 3-21^{+} \mathrm{B}$ 


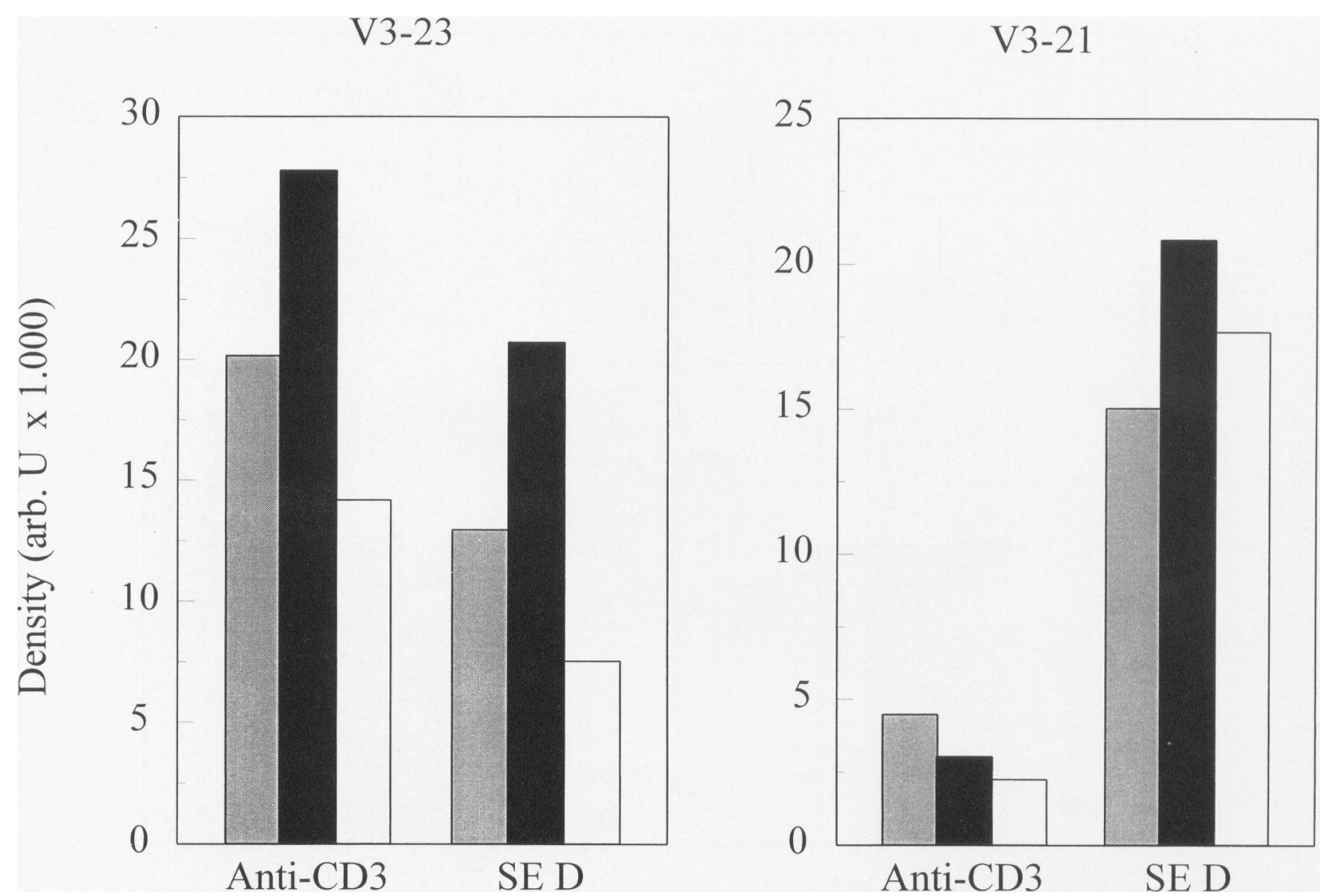

FIG. 2. Stimulation with the bacterial superantigen SE D activates $V 3-21^{+} B$ cells which are nonresponsive to anti-CD3-driven $T$ cells

$B$ cells were isolated from the peripheral blood of three donors and cocultured with either anti-CD3-activated LAB 1-10 T cells or LAB 1-10 and SE D. Cells were harvested after 20 days. cDNA was amplified with VH3- and IgM-specific primers and the concentration of V3-23 and V3-21 transcripts were semiquantified as described in Fig. 1. V3-23+ $\mathrm{B}$ cells were activated by both, anti-CD3-stimulated as well as superantigen-stimulated $\mathrm{T}$ cells. $\mathrm{V} 3-2 \mathrm{l}^{+} \mathrm{B}$ cells were nonresponsive to anti-CD3-driven T helper cells but responded in the presence of SE D.

(ם, Donor 1; 圈, Donor 2; $\square$, Donor 3).

cells. We therefore compared the proliferation of $\mathrm{V} 3-2 \mathrm{I}^{+}$and $\mathrm{V} 3-23^{+}$B cells under the two culture conditions, coculture with anti-CD3-activated $\mathrm{T}$ cells and coculture with T cells and SE D. Microcultures were harvested after 20 days and expression of V3-23 and V3-21 sequences were semiquantified by VH3-specific PCR and subsequent oligonucleotide-specific hybridization. Figure 2 shows the results from three normal individuals. Both, stimulation in the presence of anti-CD3-activated $\mathrm{T}$ cells and stimulation with SE D resulted in the induction of high concentrations of V3-23 transcripts. A different picture emerged for V3-21 ${ }^{+}$B cells. While V3-21 B cells essentially disappeared from the cultures which were anti-CD3 driven, they proliferated extensively in the presence of SE D. Thus, the activa- tion with SE D can overcome nonresponsiveness of $\mathrm{V} 3-21^{+} \mathrm{B}$ cells in normal individuals. These B cells are present in the B cell repertoire of normal healthy individuals but remain unresponsive toward helper signals provided by anti-CD3-activated $\mathrm{T}$ cells.

\section{DISCUSSION}

Production of RF represents a major immunological abnormality in patients with RA (1-3). Although it has been speculated that RFs are antibodies directed against a disease-relevant antigen, the characteristics of the RF response lends only limited support to this model. RFs are highly heterogeneous in their antigen specificity, 
are mostly of the IgM subtype, and usually do not increase in titer with chronic progression of the disease. Data presented here indicate that RA patients carry a subset of B cells which is altered in its responsiveness toward stimulatory signals. $B$ cells with the potential to secrete RFs are present in normal individuals in frequencies which are indistinguishable from those in RA patients. However, in nonrheumatoid donors, these $\mathrm{B}$ cells remain unresponsive to signals provided by anti-CD3-stimulated $\mathrm{T}$ cells. In RA patients, these signals are sufficient to induce clonal expansion of these B cells and antibody secretion.

PBMC from RA patients have a high frequency of $B$ cells secreting RF which can be expanded in cultures stimulated with activated $\mathrm{T}$ cell clones (30). Here, we report that the IgM secreted by these $\mathrm{B}$ cell clones has molecular characteristics that allowed the study of the function of this B cell subset in normals and in RA patients. $\mathrm{RF}^{+} \mathrm{B}$ cells display a nonrandom usage of $\mathrm{VH}$ gene segments with a marked overrepresentation of VH3. More importantly, the selective expression of the V3-2l gene segment in RA patients provides an opportunity to study $\mathrm{RF}^{+} \mathrm{B}$ cells. V3-2 ${ }^{+}$B cell clones were exclusively isolated from patients. We have not been able to establish $\mathrm{V} 3-21^{+}$B cell clones from a normal donor after $\mathrm{B}$ cell stimulation with anti-CD3activated $\mathrm{T}$ cell clones. The exclusive expression of V3-21 in patients' B cell clones raised the question whether such B cells were present in the repertoire of normals. Experiments demonstrating IgM transcripts using the V3-2l gene segment in unstimulated B cells from normal individuals demonstrated that patients do not have a unique germline $\mathrm{VH}$ repertoire and that normals do not delete $\mathrm{V} 3-21^{+} \mathrm{B}$ cells. Our data also suggest that the population of $\mathrm{V} 3-2 \mathrm{l}^{+} \mathrm{B}$ cells is not expanded in patients. Concentrations of V3-21-specific transcripts were similar in normal controls' and patients' B cells. Furthermore, V3$21^{+}$B cells derived from peripheral blood of normal controls can be stimulated to proliferate and to secrete antibodies with RF specificity by coculturing them with $\mathrm{T}$ cells and the bacterial superantigen SE D. The frequencies of RF-producing $B$ cells after SE D stimulation are very similar in the peripheral blood of RA patients and healthy donors. Thus, the responsiveness, rather than the presence, of $\mathrm{V} 3-21^{+}$B cells distinguishes healthy individuals and RA patients.

The association of V3-21 with RF specificity extends beyond RA. Patients with pSS, another disease characterized by RF production, share with RA patients a high frequency of RF-producing $B$ cells which respond to anti-CD3-activated $\mathrm{T}$ cells. Again, RF-producing B cells frequently utilized a V3-21 gene segment. The finding that RF activity was a feature of V3-21 B cells, irrespective of CDR3 polymorphism and $\mathrm{JH}$ gene segment usage in both diseases, indicated that the protein structure encoded by the V3-21 gene segment is directly involved in conferring antigen specificity. Usage of the V3-2l gene segment has so far not been associated with RF specificity of immunoglobulins in RA patients. However, available sequence studies on $\mathrm{RF}^{+} \mathrm{B}$ cells have almost exclusively utilized EBV-transformed $\mathrm{B}$ cells, and EBV transformation may skew the repertoire by selectively targeting certain $B$ cells. Apparently, the increased responsiveness of V3$21^{+} \mathrm{B}$ cells is shared by RA and pSS, suggesting that there may be a common pathogenetic mechanism underlying the RF production in these two distinct diseases.

Antibodies with RF specificity in normal individuals and also in RA patients frequently represent polyspecific antibodies or natural autoantibodies (31). Such natural autoantibodies are often considered to be secreted by $\mathrm{CD}^{+} \mathrm{B}$ cells $(32,33)$. The RFs studied here had characteristics which distinguished them from natural autoantibodies. Two thirds of the RFs were monospecific and did not cross-react on a panel of randomly selected antigens. Furthermore, expression of V3-21 mRNA was a feature of B cell clones derived from $\mathrm{CD}^{+}$and $\mathrm{CD}^{-} \mathrm{B}$ cells (data not shown). In summary, the experimental results support the model that a subpopulation of B cells circulates in the peripheral blood that is generally unresponsive to signals provided by polyclonally activated $\mathrm{T}$ helper cells. This B cell subpopulation is characterized by a nonrandom usage of VH gene segments and a bias for RF specificities. In disease states associated with $\mathrm{RF}$ production, these $\mathrm{B}$ cells change their reaction pattern and acquire responsiveness to antigennonspecific helper cell signals.

The mechanism underlying the distinct responsiveness of these B cells in RA is unclear and may include genetic regulation as well as exogenous stimuli. The coculture system that was employed in our studies utilized a cell-cell interaction between $B$ cells and activated $T$ cells to polyclonally stimulate B cells. It has been shown that plasma membranes of activated $\mathrm{T}$ helper cell clones can substitute for intact $\mathrm{T}$ helper cell clones in this system stressing the importance of 
cell surface molecules (34). Although other costimulatory molecules may be involved in the $\mathrm{B}$ stimulation, the cross-linking of the CD40 molecule by CD40 ligand is the most important interaction for $\mathrm{T}$ cell induced $\mathrm{B}$ cell clonal expansion (35). Apparently, the concerted action of CD40 signaling, lymphokines, and costimulatory molecules is insufficient to trigger the entry of RF-producing B cells into the cell cycle in normal individuals, while these $B$ cells are responsive in RA patients independent of exogenous antigen. Functional consequences of CD40 signaling in B cells are beginning to be understood and are probably dependent on the $B$ cell differentiation stage and $B$ cell type. In normal individuals, the V $3-21^{+} \mathrm{B}$ cells are apparently anergized by the presence of ubiquitous IgG and the absence of a cognate T-B cell interaction as introduced by the recognition of a peptidic antigen on the surface of B cells serving as APC (36). However, these $\mathrm{V} 3-21^{+} \mathrm{B}$ cells in normal individuals are responsive to exogenous stimulation as documented by the experiments utilizing the superantigen SE D. It is possible that $\mathrm{SE} D$ is directly recognized by V3-21 utilizing immunoglobulins and therefore not only acts as a $\mathrm{T}$ cell superantigen but also as a conventional B cell antigen in our culture system (17). We have previously described that SE $\mathrm{D}$ is unique among the staphylococcal enterotoxins in that it selectively induces RF production and that the $\mathrm{VH}$ repertoire of $\mathrm{B}$ cells responsive to SE D is skewed, reminiscent of the stimulation by other bacterial antigens $(15,37-39)$. It is therefore possible that previous antigenic stimulation in RA patients has rendered these $\mathrm{B}$ cells responsive to polyclonal stimulation by a CD40CD40 ligand interaction and subsequent secretion of RF.

There are at least two lines of evidence that would support the notion that the induction of $\mathrm{RF}$ in patients with RA is an antigen-specific event. First, several reports have shown that somatic mutation and affinity maturation occurs in immunoglobulins with RF specificity derived from patients with RA (40-45). Second, the production of RF appears to be an HLA-DR-associated phenomenon. HLA-DR alleles with a lysine substitution in position 71 of the $\beta 1$ chain are specifically enriched in $\mathrm{RF}^{+}$patients $(46)$. Conversely, RA patients lacking $\mathrm{RF}$ production mostly express HLA-DRB l variants with an arginine substitution in position 71 . In summary, RF synthesis appears to be an HLA-DR-linked phenomenon, probably introduced through the HLA restriction of selected helper T cells which can promote the growth and differentiation of $\mathrm{RF}^{+} \mathrm{B}$ cells. However, the V3-21 ${ }^{+}$immunoglobulin genes we have sequenced from RA and pSS patients were all of the IgM isotype and did not show somatic mutation as would have been expected after antigen-specific selection. This finding is consistent with most reports on RF sequences indicating that somatically mutated RFs represent only a small fraction of the RF in RA patients (47). It remains to be clarified whether the loss of tolerance characteristic for $\mathrm{V} 3-21^{+} \mathrm{B}$ cells in RA patients, but not in normals, is an acquired defect or a feature of the naive $B$ cell repertoire. Studies in unaffected family members of patients with $\mathrm{RF}^{+}$disease could provide insight into whether genetic mechanisms contribute to the described changes in the functional $B$ cell repertoire.

\section{ACKNOWLEDGMENTS}

The authors would like to thank Toni L. Higgins for secretarial assistance. This work is supported by grants from the National Institutes of Health (RO1 AR41974 and RO1 AR 42575) and the Mayo Foundation.

\section{REFERENCES}

1. Carson DA. (1993) Rheumatoid factor. In: Kelley WN, Harris, Jr ED, Ruddy S, Sledge CB (eds). Textbook of Rheumatology. W. B. Saunders, Philadelphia, p. 155.

2. Carson DA, Chen PP, Fox RI, et al. (1987) Rheumatoid factors and immune networks. Annu. Rev. Immunol. 5: 109-126.

3. Sasso EH, Barber CV, Nardella FA, Yount WJ, Mannik M. (1988) Antigenic specificities of human monoclonal and polyclonal IgM rheumatoid factors: The $\mathrm{C} \gamma 2-\mathrm{C} \gamma 3$ interface region contains the major determinants. J. Immunol. 140: 3098-3107.

4. Coulie PG, Van Snick J. (1985) Rheumatoid factor (RF) production during anamnestic immune responses in the mouse. III. Activation of RF precursor cells is induced by their interaction with immune complexes and carrier-specific helper T cells. J. Exp. Med. 161: 88-97.

5. Williams Jr RC, Kunkel HG. (1962) Rheumatoid factor, complement, and conglutinin aberrations in patients with subacute bacterial endocarditis. J. Clin. Invest. 41: 666 . 
6. Carson DA, Chen PP, Kipps TJ. (1991) New roles for rheumatoid factor. J. Clin. Invest. 87: 379-383.

7. Roosnek E, Lanzavecchia A. (1991) Efficient and selective presentation of antigen-antibody complexes by rheumatoid factor B cells. J. Exp. Med. 173: 487-489.

8. Lanzavecchia A. (1990) Receptor-mediated antigen uptake and its effect on antigen presentation to class II-restricted T lymphocytes. Annu. Rev. Immunol. 8: 773-793.

9. Metlay JP, Pure E, Steinman RM. (1989) Control of the immune response at the level of antigen-presenting cells: a comparison of the function of dendritic cells and B lymphocytes. Adv. Immunol. 47: 45-116.

10. Kipps TJ, Duffy SF. (1991) Relationship of the CD5 B cell to human tonsillar lymphocytes that express autoantibody-associated cross-reactive idiotypes. J. Clin. Invest. 87: 2087-2096.

11. Tighe H, Chen PP, Tucker R, et al. (1993) Function of B cells expressing a human immunoglobulin $\mathrm{M}$ rheumatoid factor autoantibody in transgenic mice. J. Exp. Med. 177: 109-118.

12. Borretzen M, Randen I, Zdarsky E, Forre O, Natvig JB, Thompson KM. (1994) Control of autoantibody affinity by selection against amino acid replacements in the complementarity-determining regions. Proc. Natl. Acad. Sci. U.S.A. 91: 12917-12921.

13. Arnett FC, Edworthy SM, Bloch DA, et al. (1988) The American Rheumatism Association 1987 revised criteria for the classification of rheumatoid arthritis. Arthritis Rheum. 31: 315-324.

14. Vitali C, Bombardieri S, Moutsopoulos HM, et al. (1993) Preliminary criteria for the classification of Sjögren's syndrome. Results of a prospective concerted action supported by the European Community. Arthritis Rheum. 36: 340-347.

15. He X, Goronzy J, Weyand C. (1992) Selective induction of rheumatoid factors by superantigens and human helper T cells. $J$. Clin. Invest. 89: 673-680.

16. Thiele DL, Lipsky PE. (1986) The immunosuppressive activity of L-Leucyl-L-Leucine methylester: Selective ablation of cytotoxic lymphocytes and monocytes. J. Immunol. 136: $1038-1048$.

17. Xie C, Brühl H, He X, Weyand CM, Goronzy JJ. (1995) Selective activation of $\mathrm{L} \mathrm{A} 10^{+}$ rheumatoid factor producing $B$ cells by the staphylococcal enterotoxin D. Int. Immunol. 7: $425-434$.

18. Stoflet ES, Koeberl DD, Sarkar G, Sommer SS. (1988) Genomic amplification with transcript sequencing. Science 239: 491-494.

19. Pascual V, Capra JD. (1991) Human immunoglobulin heavy-chain variable region genes: Organization, polymorphism, and expression. Adv. Immunol. 49: 1-74.

20. Schroeder Jr HW, Wang JY. (1990) Preferential utilization of conserved immunoglobulin heavy chain variable gene segments during human fetal life. Proc. Natl. Acad. Sci. U.S.A. 87: 6146-6150.

21. Ichihara Y, Matsuoka H, Kurosawa Y. (1988) Organization of human immunoglobulin heavy chain diversity gene loci. $E M B O J$. 7: 4141-4150.

22. Buluwela L, Albertson DG, Sherrington $P$, Rabbitts PH, Spurr N, Rabbitts TH. (1988) The use of chromosomal translocations to study human immunoglobulin gene organization: mapping $\mathrm{D}_{\mathrm{H}}$ segments within $35 \mathrm{~kb}$ of the $C_{\mu}$ gene and identification of a new $D_{H}$ locus. EMBO J. 7: 2003-2010.

23. Sonntag $D$, Weingärtner $B$, Grützmann R. (1989) A member of a novel human DH gene family: DHFL16. Nucleic Acid Res. 17: 1267.

24. Matsuda F, Shin EK, Hirabayashi Y, et al. (1990) Organization of variable region segments of the human immunoglobulin heavy chain: duplication of the $\mathrm{D}_{5}$ cluster within the locus and interchromosomal translocation of variable region segments. $E M B O J$. 9: 2501-2506.

25. Hillson JL, Oppliger IR, Sasso EH, Milner EC, Wener MH. (1992) Emerging human B cell repertoire. Influence of developmental stage and interindividual variation. J. Immunol. 149: 3741-3752.

26. Matsuda F, Shin EK, Nagaoka $H$, et al. (1993) Structure and physical map of 64 variable segments in the $3^{\prime} 0.8$-megabase region of the human immunoglobulin heavy-chain locus. Nature Genet. 3: 88-94.

27. Cook GP, Tomlinson IM, Walter G, et al. (1994) A map of the human immunoglobulin $\mathrm{V}_{\mathrm{H}}$ locus completed by analysis of the telomeric region of chromosome 14q. Nature Genet. 7: 162-168.

28. Mortari F, Wang JY, Schroeder Jr HW. (1993) Human cord blood antibody repertoire. Mixed population of $\mathrm{VH}$ gene segments and CDR3 distribution in the ex- 
pressed $\mathrm{C} \alpha$ and $\mathrm{C} \gamma$ repertoires. J. Immunol. 150: $1348-1357$.

29. Walser-Kuntz DR, Weyand CM, Weaver AJ, O'Fallon WM, Goronzy JJ. (1995) Mechanisms underlying the formation of the $\mathrm{T}$ cell receptor repertoire in rheumatoid arthritis. Immunity 2: 597-605.

30. He X, Goronzy JJ, Weyand CM. (1993) The repertoire of rheumatoid factor producing $\mathrm{B}$ cells responsive to bacterial superantigen and bystander help in normals and patients with rheumatoid arthritis. Arthritis Rheum. 36: 1061-1069.

31. Burastero SE, Casali P, Wilder RL, Notkins AL. (1988) Monoreactive high affinity and polyreactive low affinity rheumatoid factors are produced by $\mathrm{CD}^{+} \mathrm{B}$ cells from patients with rheumatoid arthritis. J. Exp. Med. 168: 1979-1992.

32. Hardy RR, Hayakawa K, Shimizu M, Yamasaki K, Kishimoto T. (1987) Rheumatoid factor secretion from human Leu- ${ }^{+}$B cells. Science 236: 81-83.

33. Casali P, Burastero SE, Nakamura M, Inghirami G, Notkins AL. (1987) Human lymphocytes making rheumatoid factor and antibody to ssDNA belong to Leu- ${ }^{+}$B-cell subset. Science 236: 77-81.

34. Tohma S, Lipsky PE. (1991) Analysis of the mechanisms of $T$ cell-dependent polyclonal activation of human $B$ cells. Induction of human $\mathrm{B}$ cell responses by fixed activated $\mathrm{T}$ cells. J. Immunol. 146: 2544-2552.

35. Banchereau J, Bazan F, Blanchard D, et al. (1994) The CD40 antigen and its ligand. Ann. Rev. Immunol. 12: 881-922.

36. Cooke MP, Heath AW, Shokat KM, et al. (1994) Immunoglobulin signal transduction guides the specificity of $\mathrm{B}$ cell-T cell interactions and is blocked in tolerant self-reactive B cells. J. Exp. Med. 179: 425-438.

37. Lucas AH. (1988) Expression of crossreactive idiotypes by human antibodies specific for the capsular polysaccharide of Hemophilus influenzae B. J. Clin. Invest. 81: 480-486.

38. Adderson EE, Shackelford PG, Quinn A, Carroll WL. (1991) Restricted Ig H chain V gene usage in the human antibody response to Hemophilus influenzae type b capsular polysaccharide. J. Immunol. 147: 1667-1674.

Contributed by G. J. V. Nossal on August 3, 1995.
39. Silverman GJ. (1992) Human antibody responses to bacterial antigens: Studies of a model conventional antigen and a proposed model B cell superantigen. Int. Rev. Immunol. 9: $57-78$.

40. Olee T, Lu EW, Huang D-F, et al. (1992) Genetic analysis of self-associating immunoglobulin $G$ rheumatoid factors from two rheumatoid synovia implicates an antigendriven response. J. Exp. Med. 175: 831-842.

41. Lee SK, Bridges Jr SL, Koopman WJ, Schroeder Jr HW. (1992) The immunoglobulin kappa light chain repertoire expressed in the synovium of a patient with rheumatoid arthritis. Arthritis Rheum. 35: 905-913.

42. Randen I, Brown D, Thompson KM, et al. (1992) Clonally related IgM rheumatoid factors undergo affinity maturation in the rheumatoid synovial tissue. J. Immunol. 148: 3296-3301.

43. Fang Q, Kannapell CC, Gaskin F, Solomon A, Koopman WJ, Fu SM. (1994) Human rheumatoid factors with restrictive specificity for rabbit immunoglobulin G: Auto- and multi-reactivity, diverse $\mathrm{VH}$ gene segment usage and preferential usage of V $\lambda$ IIIb. $J$. Exp. Med. 179: 1445-1456.

44. Youngblood K, Fruchter L, Ding G, Lopez J, Bonagura V, Davidson A. (1994) Rheumatoid factors from the peripheral blood of two patients with rheumatoid arthritis are genetically heterogeneous and somatically mutated. J. Clin. Invest. 93: 852-861.

45. Lee SK, Bridges Jr SL, Kirkham PM, Koopman WJ, Schroeder Jr HW. (1994) Evidence of antigen receptor-influenced oligoclonal B lymphocyte expansion in the synovium of a patient with longstanding rheumatoid arthritis. J. Clin. Invest. 93: 361-370.

46. Weyand CM, McCarthy TG, Goronzy JJ. (1995) Correlation between disease phenotype and genetic heterogeneity in rheumatoid arthritis. J. Clin. Invest. 95: 2120-2126.

47. Randen I, Thompson KM, Pascual V, et al. (1992) Rheumatoid factor $V$ genes from patients with rheumatoid arthritis are diverse and show evidence of an antigen-driven response. Immunol. Rev. 128: 49-71. 